\title{
Las comuniones en Castellón desde principios del s. $\mathbf{x x}$
}

\author{
Lourdes Alaiz Lavernia
}

A lo largo del pasado s. xx y cuando se aproximaba el mes de mayo, en donde habían niños en edad de comulgar, se preparaba todo aquello que constituía tan magno acontecimiento: los vestidos, los trajes, el convite, pintar la casa, arreglar la habitación, la catequesis, la fotografía, las estampas, los recordatorios, etc.

Desde el mes de septiembre, los futuros comulgantes acudían a la catequesis (que denominaban la doctrina), bien en la propia iglesia parroquial o en las casas de las catequistas; más adelante se dispuso de salones parroquiales y las catequistas y los niños acudían una o dos veces por semana.

El aprendizaje se basaba en el estudio y la memorización de un librito titulado Catecismo de la Doctrina Cristiana, en su contenido figuraban todas las oraciones tales como: el padrenuestro, el avemaría, yo pecador, etc., y las obras de misericordia, las bienaventuranzas, los mandamientos de la ley de Dios y de la Santa Madre Iglesia, etc. Debían saber todo su contenido para poder comulgar.

Otro de los preparativos era el de la confección del traje o vestido para ese día, que era mantenido en secreto con el fin de no ser copiado. Las niñas vestían de blanco y los niños con trajes modelo marinero, almirante o trajes de calle de color azul, negro o marrón, pero adornados con fajines y lazos de raso bordado sobre la manga izquierda.

En los comienzos del s. xx, las niñas llevaban el traje por encima del tobillo y la manga larga, com- plementado por sombrero, diadema, corona de flores, casquete y un velo todo de blanco impoluto; más avanzado el siglo, hacia los años 30 , se alargó el vestido hasta los pies y se introdujo la moda de vestir telares semejantes a órdenes religiosas pero en blanco y, sobre los años 60, cayó en desuso el velo y las mangas se acortaron siendo denominadas de farolillo. Los complementos que acompañaban y enriquecían estos trajes eran: misal, abanico, limosnera, guantes, rosario y lazos que fueron perdiendo protagonismo, aunque se ha conservado el misal para niños y niñas y la limosnera.

Los lutos y el vestir de negro, moda introducida en España por Felipe II, era la manera de vestir cuando se producía un óbito más o menos cercano y, durante años, y las señoras iban vestidas desde la cabeza a los pies de negro riguroso, la cabeza iba

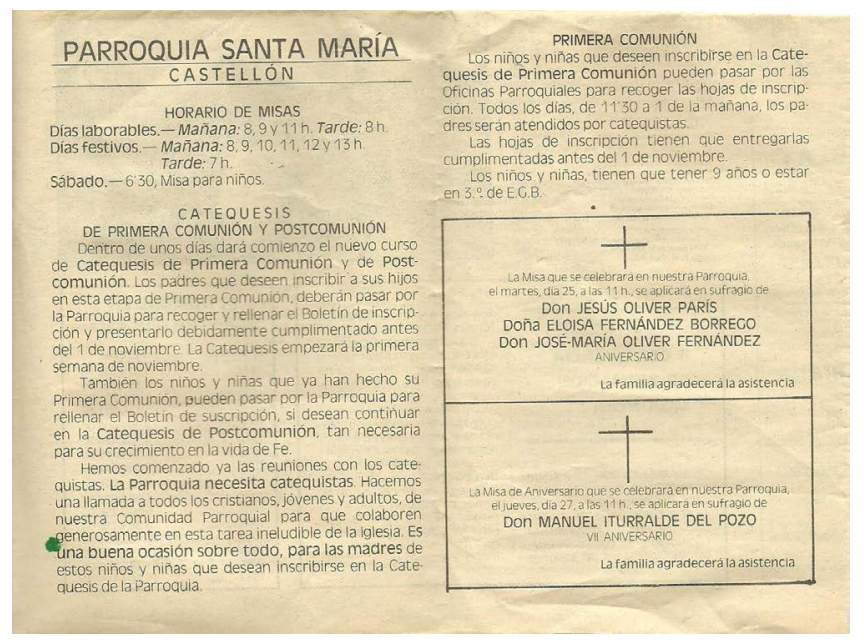

Figura 1. Hoja parroquial de 1988 


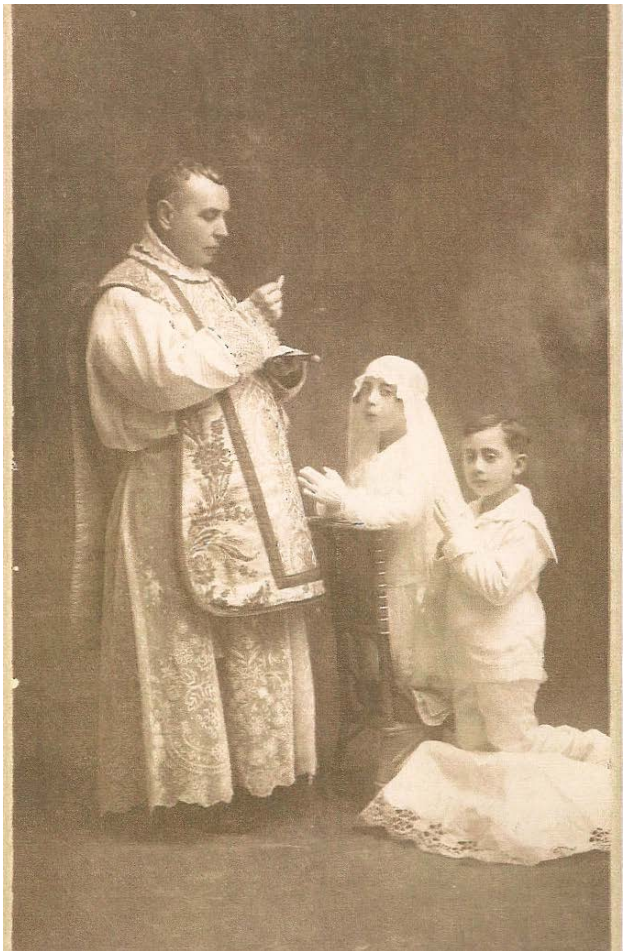

Figura 2. Hermanos Sánchez (año 1920)

cubierta por un manto (parecido a los actuales fulares) y recogido en los brazos; después de un año, lo cambiaban por un velo corto que aquí se llamaba velet, prendido con alfileres al pelo y recogido al cuello. Los caballeros vestían traje negro, camisa blanca y corbata negra, como los zapatos; quien tenía un traje azul marino, marrón o gris, se acompañaba de camisa blanca, corbata negra, un botón negro en el ojal de la solapa y un brazalete negro en la manga izquierda. De estos lutos no escapaban los niños y, con los trajes ya en marcha, eran tintados de negro total y absoluto; en el caso de ser niñas, hasta el velo de tul. No olvidemos que la mortandad que produjo en España la temida gripe asiática, conocida como la cucaracha, que mermó considerablemente la población; aunque suene macabro, sí algún niño o niña fallecía recién tomada la comunión, eran enterrados con sus trajes. Lamentablemente, eran tiempos en los que la sociedad del momento tenía estas costumbres.

Las casas solían remozarse pintando las fachadas y las habitaciones de los niños.

El convite o ágape se hacía en las propias casas; consistía en chocolate caliente y pastas fabricadas por la familia o bien se contrataban los servicios de alguna señora dedicada para tal fin, que esta- ban muy solicitadas. Una vez preparadas para la cocción, se depositaban sobre bandejas y estas, a su vez, en una tabla rectangular. Era curioso ver el trasiego camino al horno de señoras que, sobre la cabeza, llevaban la tabla ayudándose del rodete (capsana), con un delantal blanco y cubriendo sendos antebrazos con manguitos blancos. La rivalidad entre las familias era grande: «Que si yo he hecho más y mejores productos y tú menos». ¡Cosas de entonces!

Los abuelos y los padrinos tenían relevancia especial, ya que solían ser quienes pagaban los trajes, los aderezos y todos aquellos adornos que acompañaban a los trajes. También tenían sus más y sus menos.

Los niños y las niñas, muchas veces heredaban los trajes de sus hermanos mayores y, si coincidían dos hermanos que se llevaran una diferencia de uno o dos años, comulgaban juntos.

Los recordatorios (figura 3) eran estampas, que bien se pintaban a mano sobre pergamino o algún tipo de papel vegetal o bien se mandaban a la imprenta. Las estampas pintadas eran mucho más vistosas por el colorido y las impresas solían tener representaciones de la vida de Jesús, pero su color era en sepia o negro; a mediados de siglo ya se imprimían en color y sus imágenes no eran tan sórdidas y se tomaban de cuadros de algún pintor famoso o de dibujos infantiles en los que se representaba al niño Jesús. Estas estampas eran repartidas por los comulgantes entre amistades y vecinos, recibiendo a cambio un óbolo, por lo general dinero que era depositado en la limosnera.

¡Llegamos al día grande! Previamente, el día anterior, la iglesia era motivo de reunión de madres, sacerdote y sacristán, para adecentar y adornar el altar con bonitos manteles de hilo y vainicas y anchas puntillas de crochet o bolillos realizadas por alguna feligresa; además, situaban estratégicamente macetas y ramos de flores. Los niños acudían a la barbería en donde el señor barbero procedía a arreglarles y repasarles el pelo; las niñas solían recibir en sus casas a peluqueras itinerantes que les acondicionaban sus cabellos para poder lucir unos flamantes tirabuzones (¡pobre niña sí tenía el pelo superliso!) que cargaban todo el día con bigudíes y muchas pinzas para luego darle forma con unas 


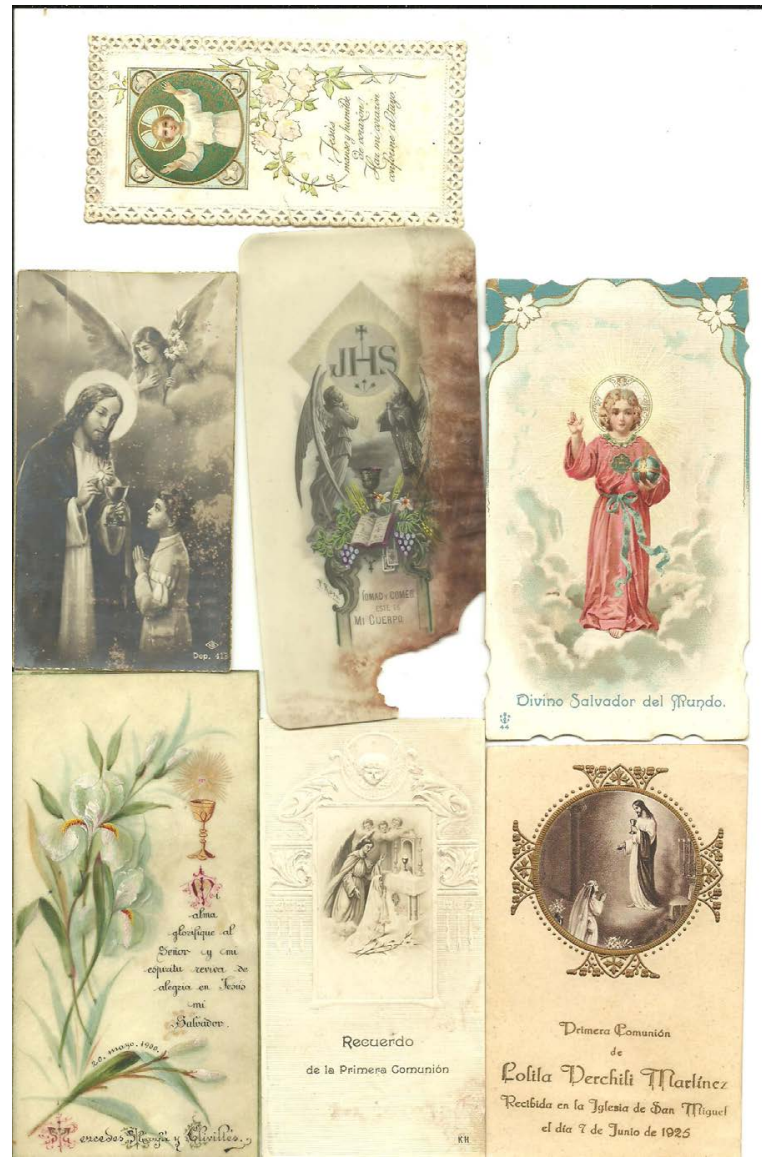

Figura 3. Diferentes recordatorios anteriores a 1936

tenacillas que ponían sobre el fuego. También eran convocados por el sacerdote para confesarles. Ya llegó el día, por norma el de la Ascensión.

Temprano se despertaba al comulgante, se le aseaba y vestía con sus galas, pero recordándole en todo momento que no podía beber ni agua, ya que era perceptivo el estar 12 horas en ayuno total; si algún inocente se saltaba esta norma, indudablemente no recibía el cuerpo de Cristo.

Las puertas de las casas eran adornadas con flores y ramas y, en el suelo, una alfombra de hojas. Se dirigían todos los acompañantes en comitiva hacia la iglesia y se acomodaban en sillas (para las niñas, dos por el volumen del traje) delante del altar; los padres, en la parte de atrás y, en el momento de recibir la comunión, se acercaban para acompañar a sus hijos.

Algunos niños comulgaban en capillas de comunidades religiosas ellos solos, ya que los padres eran benefactores o bien tenían alguna religiosa familiar. En los años 70, los niños y las niñas que

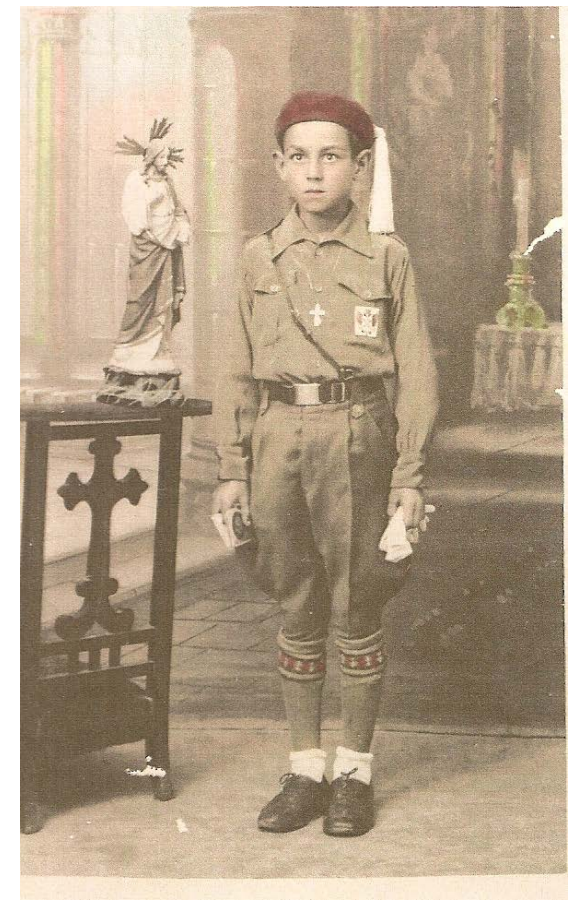

Figura 4. Francisco Ginés vestido de Pelayo 1939

eran alumnos de colegios regidos por religiosos tomaban la comunión en su capilla; en un principio cada uno iba con el traje que sus padres habían elegido, pero más tarde se impuso la moda de túnicas $y$, en la actualidad, se vuelve a llevar el traje que escogen los padres.

Las fotografías de antaño se realizaban bien en estudios fotográficos en la capital como el de Germán Colón o por fotógrafos que se desplazaban a los pueblos y su presencia era anunciada por el aguacil mediante un bando; todas aquellas familias que lo deseaban acudían al lugar convocado con sus hijos, con las galas de tan fausto día. Ya en los años 50 y 60, estas fotos eran repartidas entre los más allegados.

Hoy, tanto los trajes de niños como de niñas han cambiado; antiguamente eran confeccionados por modistas como Doloretes Carregui, Paquita Verchili (la del corte), Lolita León, las hermanas Biosca, etc. y sastres como Loras y otros más. También se solían coser en casa por la madre ayudada por una costurera. En la actualidad, se pueden adquirir en numerosos establecimientos dedicados a tal fin.

La catequesis es más abierta desde la celebración del Concilio Vaticano II y el ayuno ya no es de 12 horas. 
La elaboración de pastas apenas se hace pero, si se celebra en las propias casas, bajos y jardines particulares, se suele contratar un servicio de cáterin en alguna de las numerosas pastelerias que hay; otros optan por un restaurante.

Una vez pasada la celebración de la primera comunión, llega la festividad del Corpus Christi, celebrándose la procesión con el Santísimo en la que toman parte numerosos comulgantes con sus galas, que recorren las calles del centro de las ciudades y pueblos y desde los balcones son arrojados pétalos de rosa, así como enramadas.

Concluyendo, desde antiguo, las comuniones han tenido un papel relevante en la sociedad española. 